Dept of Biochemistry, Faculty of Vet. Med.,

Suez Canal University.

\title{
BIOCHEMICAL AND SEROLOGICAL STUDIES ON THE PROTECTIVE EFFECT OF BLACK SEEDS IN EXPERIMENTALLY INFECTED BROILER WITH GUMBORO \\ (With 8 Tables and One Figure)
}

By

I. ASHOUR IBRAHIM; ABD AL-R. EL-GHANNAM; ABEER GAFFER ALI HASSAN; DALIA MANSOUR HAMED* and AISHA IBRAHIM EL-RAYES

*Dept. of Poultry and Rabbit Med., Faculty of Vet. Med., Suez Canal University (Received at 14/9/2011)

دراسات بيوكيميائية ومصليه عن التأثير الوقائى لبذور الحبة السوداء على التي

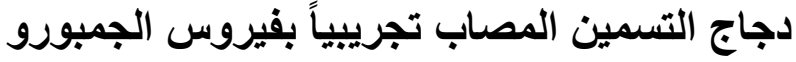

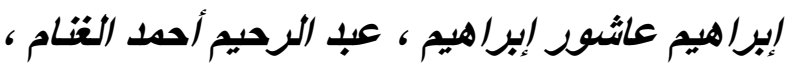

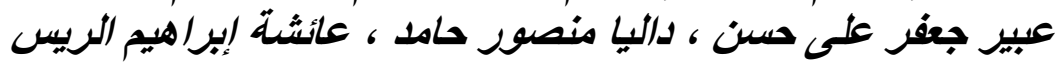

اجريت الدراسة على 130 كتكوت قسمت الى اربع مجمو عات (معالجة ببذور الحبة السوداء-

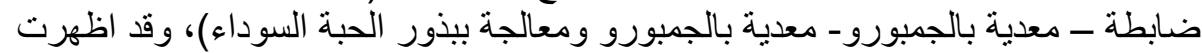

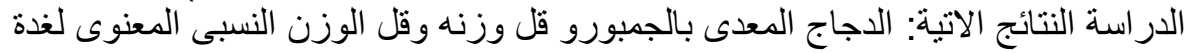

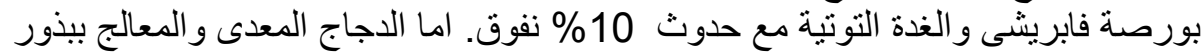

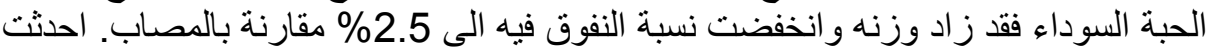

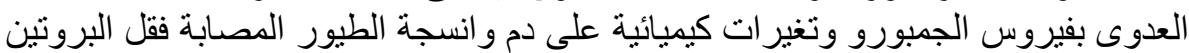

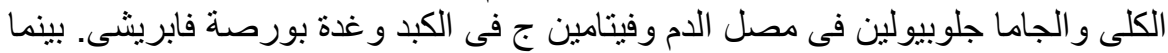

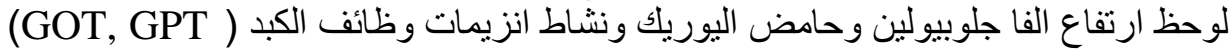

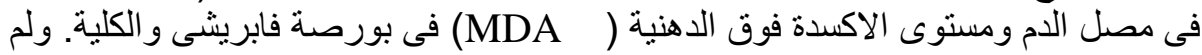

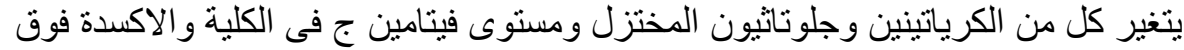

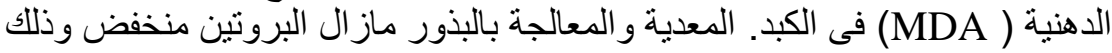

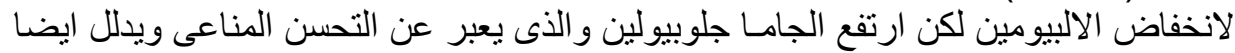

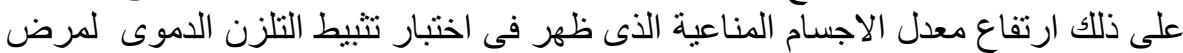

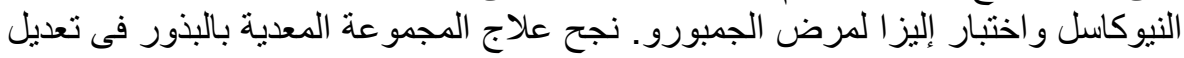




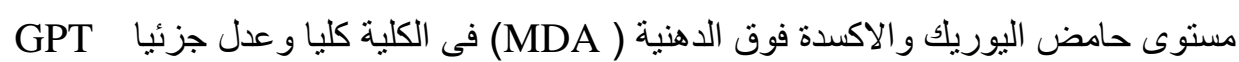

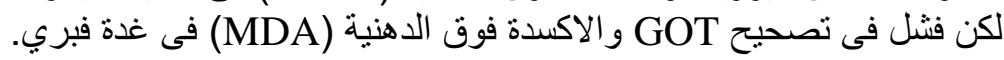

\section{SUMMARY}

The study was carried out to know the effect of black seeds on chicken experimentally infected with Gumboro virus. A total of 130 chicks were used. Experimental birds were divided into 4 groups. The first group of 20 birds was treated with black seed, second group consist of 30 birds was kept as non-infected non-treated control, third group of 40 birds was infected with IBDV, while fourth group of 40 birds represented SBDV infected and black seed treated birds. Infected chicks showed decreased body weight, bursal and thymus indices with $10 \%$ mortality. Infected birds treated with black seeds showed an increase in body weight with $2.5 \%$ mortality. Gumboro infection induced biochemical alterations in blood and tissues of infected birds. It decreased total protein, $\gamma$ globulin, hepatic and bursal ascorbic acid. While it increased $\alpha 1$ globulin, uric acid, GOT, GPT, bursal and renal MDA. With no alterations in creatinine, GSH, renal ascorbic and hepatic MDA. Infected birds treated with black seeds had decreased total protein and albumin but immunity is raised as shown by increasing $\gamma$ globulin and antibody titers which detected by HI and ELISA testes for NewCastle and Gumboro viruses. Treated Infected birds with black seeds succeed to restore uric acid, renal MDA and partially GPT but failed to restore GOT and bursal MDA. In conclusion, black seeds showed its cytoprotective, antioxidant and antiviral effect through its non specific immunostimulant role against Gumboro virus challenged birds.

Key words: Gumboro (IBD), Black seeds, antioxidants- liver and kidney function tests, ELISA antibody titer, immunosuppresion.

\section{INTRODUCTION}

Poultry is now being recognized as a most popular enterprise due to less investment and quick return. Due to high demand of animal protein in our country, only this sector can provide sufficient valuable protein to meet up needs. But, practically, it is really troublesome to attain the peak production overcoming several constraints like, vaccination failure, feed adulteration and diseases etc. One of the most 
critical diseases is Gumboro which is the second most important viral disease after Newcastle (Abd El-Rahman et al., 2007).

Gumboro Disease (GD), called Infectious Bursal Disease (IBD), is a highly contagious viral one. It was first recognized in Gumboro district of Delware, USA (Cosgrove 1962).

In Egypt, IBD was reported for the first time by El- Sergany et al. (1974) in the commercial broiler chicken on the basis of pathological examination. The causative agent was isolated and identified by Ayoub and Malek (1976). In 1990, El-Batrawy was the first one who reported on the emergence of severe outbreaks of very virulent infectious bursal disease virus (VVIBDV). Later on, many similar outbreaks were reported and described in various governorates with severe pathological lesions and high mortality up to $70 \%$ in replacement commercial layer pullets and up to $30 \%$ in meat type chicken (Ahmed 1991; Madbouly et al., 1992). IBDV cause severe lesions on the bursa of Fabricious and other organs such as: spleen, thymus and kidneys, and may induce immune suppression and mortality in birds (McFerran 1993). The clinical forms of IBD usually occur in chicken from 3-6 weeks of age. The clinical disease has a sudden onset, and the mortality rate in the flock increases rapidly. Clinical signs of the disease include dehydration, trembling, ruffled feathers, vent pecking and depression. Affected chicken had a transient immunosuppression. On necropsy, the principle lesions are found in the bursa of Fabricious (Butcher and Miles 2003).

IBDV is resistant to many disinfectants and environmental factors. Chicks grown on these farms typically have poor body weights, high mortality, excessive reactions to respiratory vaccines and high rates of condemnation during processing. The subclinical form of the disease occurs in chicken less than 3 weeks of age with no clinical signs of disease, but showed permanent and severe immunosuppression (Lukert 1992).

Nigella sativa seeds called (Black seeds, or Black cumin), Seeds and its product are one of the most commonly used medicinal plants. Much of the biological activity of the seeds has been shown to be due to thymoquinone (TQ), the major component of its essential oil (Mansour et al., 2002). The seeds have immunostimulant, anti-inflammatory, antimicrobial, analgesic, antipyretic and antineoplastic activity. It would 
appear that the beneficial effects of the use of the seeds and thymoquinone might be related to their cytoprotective and antioxidant actions (Ali and Blunden 2003).

So, the aim of this work is to study the effect of infection with IBDV and evaluate the ability of black seed, to protect from undesirable changes through:

A- Performance parameters as (Mean body weight, bursal and thymus indices, mortality rate).

B- biochemical parameters (Serum total protein and its fractions, Uric acid, Creatinine, GOT and GPT, blood reduced glutathione(GSH), Serum and tissues malondialdhyde (MDA), tissues ascorbic acid. Haemagglutination inhibition Test (HI) against Newcastle Virus (NDV). ELISA Antibody Titer aganist Gumboro Virus.

\section{MATERIALS and METHODS}

One hundred and thirty one day old broiler chicks, Hubbard breed were obtained from Ismailia Poultry Company, Serapum, Ismailia, Egypt. Chicken were reared on litter under standard environmental and hygienic conditions. The temperature was adjusted according to the age (the first week $32^{\circ} \mathrm{C}$ and decreased $2{ }^{\circ} \mathrm{C}$ per week) (Harrison and Harrison, 1986).

Chicken were fed on a balanced commercial diet and water were added ad libitum.

As shown in Table (1): All chicken were vaccinated by vaccines produced by "Vet. Vacc. Res. Inst." Vetrinary Vaccines Research Institute Cairo, Egypt according to (Giambrone and Ronald 1986). Black seed powder was added to ration as $2 \mathrm{~g} / \mathrm{kg}(0.2 \%)$ according to Hanan El Dahshan (2002) during the whole raising period.

Experimental Infection: Challenge virus Sultan H A Strain, Sultan 95, Monofia University, Elsadat Fac. of Vet. Med. was used. The stock virus was diluted 1:10 in phosphate buffer saline (PBS) and administrated by putting one drop into eye of the bird (Helmboldet and Garner 1964). The infection was applied for the chicken at 28 days old, symptoms appeared three days later. Birds were weighed every week along the whole raising period.

Table 1: Experimental Design 


\begin{tabular}{|l|c|c|c|c|c|}
\hline \multicolumn{1}{|c|}{ Groups } & No. & $\begin{array}{c}\text { Experimentally } \\
\text { infected }\end{array}$ & $\begin{array}{c}\text { Black } \\
\text { seeds }\end{array}$ & Sampling & Vaccination \\
\hline $\begin{array}{l}\text { Black } \\
\text { seed (G1) }\end{array}$ & 20 & Non & $\begin{array}{l}2 \mathrm{~g} / \mathrm{kg} \\
\text { ration }\end{array}$ & $\bullet$ Blood \& Tissue \\
sample at $3^{\text {rd }} \& 5^{\text {th }}$ \\
days PI for \\
biochemical \\
parameters \\
$\begin{array}{l}\text { Control } \\
(\mathrm{G} 2)\end{array}$
\end{tabular}

Samples: samples were collected three times at 3, 5 and 14 days postinoculation (PI) of the virus. Two blood samples were obtained from wing vein of each bird. The first sample was collected in a clean tube containing heparin as anticoagulant (cium-heparin 5000 I.U) to get whole blood to estimate blood reduced glutathione content (GSH) (Beutler et al., 1963). The second blood sample was taken into a clean and dry screw capped centrifuge tubes and left to clot at room temperature, then centrifuged at $3000 \mathrm{rpm}$ for 15 minutes to separate clear serum for determination of the different biochemical parameters such as total protein level (Gornal et al., 1949) and its fractions by electrophoresis (Ritzmann and Daniel 1982), uric acid and creatinine levels (Bartels (1971) and Young (2001) respectively), liver enzymes (GOT and GPT) activities, (Scherwin et al., 2003) and serum malondialdhyde (MDA) level (Yoshioko et al., 1979). Haemagglutination inhibition (HI) test against NDV in serum according to Hanson et al. (1978), ELISA antibody titer for IBDV in serum: Detection of antibodies to IBD virus was done according to FLOCK SCREEN ELISA test to estimate the most appropriate time for vaccination to monitor vaccination response and to confirm exposure to disease.

Tissue samples: birds were sacrificed and dissected to obtain bursa of Fabricious, thymus, liver and kidney. These organs were weighed, 
washed with normal saline and kept in deep freezer at $20^{\circ} \mathrm{C}$ for determination of tissue malondialdhyde (MDA) level (Yoshioko et al., 1979), tissues vitamin C value (Roe et al., 1948).

Determination of performance parameters: Mean body weight, Bursal and thymus indices according to Dalia Mansour (2003).

Statistical analysis was done according to (Duncan 1955) by using a computer program one way completely randomized Analysis of variance test"F Test" (ANOVA)

\section{RESULTS and DISCUSSION}

Infectious Bursal Disease (IBD) or Gumboro disease is a viral disease of young growing chicken occurring in most poultry producing areas of the world. Its causative virus is extremely stable and resistant to disinfectants and normal sanitation measures. Once established in a farm, the disease tends to recur with each succeeding flock (Kenton 2003). Affected chicks experience transient immunosupression. (Butcher and Miles 2003).

\section{Performance parameters:}

Mean body weight (Table 2): Our result revealed that the infected birds survived from the disease at 32 days old showed significant loss in weight in comparison with control. Similar finding were reported by Tsukamoto et al. (1992). Other studies showed also that SBD in chicken occurred in acute and subclinical forms characterizes by high morbidity \& mortality was accompanied by marked immunosuppression, lowered flock resistance, poor weight gain, and increased feed conversion ratio Paul et al. (2004). The loss of weight is due to less feed intake and diarrhea. Sever hemorrhage on the thigh and breast muscles that strongly arrests the proper muscle development in the affected broilers. By end of the experiment there was significant increase in the mean body weight in black seeds group (G1) in comparison with Control group (G2). The mean body weight of infected broiler chicken feed black seeds (G4) was higher than the infected group (G3), while both were lower than control group (G2).

Table 2: Effect of Black Seed on the Mean Body Weight in (g) in different groups 
Assiut Vet. Med. J. Vol. 57 No. 131 October 2011

\begin{tabular}{|c|c|c|c|c|c|c|}
\hline $\begin{array}{c}\text { Days } \\
\text { age }\end{array}$ & 10 days & 17 day & 24 day & 32 day & 40 days & Mortality \\
\hline $\begin{array}{c}\text { Black Seed } \\
\text { G1 }\end{array}$ & $\begin{array}{r}a \\
172 \pm 7.0\end{array}$ & $\begin{array}{r}a \\
466 \pm 14.2\end{array}$ & $\begin{array}{r}a \\
908 \pm 18.7\end{array}$ & $\begin{array}{r}\mathrm{a} \\
1110 \pm 17.0\end{array}$ & $\begin{array}{r}a \\
1556 \pm 32.6\end{array}$ & $0 \%$ \\
\hline $\begin{array}{l}\text { Control } \\
\text { G2 }\end{array}$ & $184 \pm 5.0$ & $\begin{array}{r}\text { b } \\
374 \pm 10.6\end{array}$ & $\begin{array}{r}b \\
825 \pm 19.5\end{array}$ & $\begin{array}{r}\mathrm{a} \\
1060 \pm 11.1\end{array}$ & $\begin{array}{r}b \\
137 \pm 30.5\end{array}$ & $0 \%$ \\
\hline $\begin{array}{l}\text { Infected } \\
\text { G3 }\end{array}$ & -- & -- & --- & $\begin{array}{r}\text { c } \\
828 \pm 21.7\end{array}$ & $1146 \pm 26.0$ & $2.5 \%$ \\
\hline $\begin{array}{c}\text { Infected } \\
\text { Black Seed } \\
\text { G4 }\end{array}$ & -- & -- & ---- & $947 \pm 18.2$ & $1203 \pm 36.7$ & $10 \%$ \\
\hline
\end{tabular}

Values expressed as Mean \pm SE $\quad$ PI $=$ Post Inoculation

Values with different letters in the same column are significantly different

The highest body weight gain of black seed treated group in our result were agreed with Abdo (2004) and Nabila et al. (2006) who reported the efficacy of black seeds in improving the body weight gain without any adverse effects on blood component and in Contrary Zaoui et al. (2002) observed significant slowdown of the body weight in black seeds treated animals comparatively to control group.

In broiler, the bursa functions as half of the bird's immune system and the size of bursa reflects the bird's overall health status. 
Bursa size and weight are a biological measures of how well flocks are managed and protected from diseases.

Table 3: Effect of black seed on bursal and thymus indicies of experimentally infected chicken with IBDV.

\begin{tabular}{|c|c|c|c|c|c|c|}
\hline & \multicolumn{3}{|c|}{ Bursal Index } & \multicolumn{3}{|c|}{ Thymus Index } \\
\hline Groups & 3 days P.I & 5 days P.I & 14 days P.I & 3 days P.I & 5 days P.I & 14 days P.I \\
\hline $\begin{array}{c}\text { Black Seed } \\
\text { G1 }\end{array}$ & $\begin{array}{c}a b \\
0.06 \pm 0.006\end{array}$ & $\begin{array}{c}b \\
0.04 \pm 0.006\end{array}$ & $\begin{array}{c}b \\
0.05 \pm 0.006\end{array}$ & $\begin{array}{c}a \\
0.23 \pm 0.005\end{array}$ & $\begin{array}{c}b \\
0.10 \pm 0.005\end{array}$ & $\begin{array}{c}b c \\
0.07 \pm 0.006\end{array}$ \\
\hline $\begin{array}{c}\text { Control } \\
\text { G2 }\end{array}$ & $\begin{array}{c}a \\
0.08 \pm 0.006\end{array}$ & $\begin{array}{c}a \\
0.07 \pm 0.003\end{array}$ & $\begin{array}{c}a \\
0.09 \pm 0.006\end{array}$ & $\begin{array}{c}a \\
0.24 \pm 0.006\end{array}$ & $\begin{array}{c}a \\
0.14 \pm 0.006\end{array}$ & $\begin{array}{c}a \\
0.16 \pm 0.005\end{array}$ \\
\hline $\begin{array}{l}\text { Infected } \\
\text { G3 }\end{array}$ & $\begin{array}{c}c \\
0.02 \pm 0.005\end{array}$ & $\begin{array}{c}\mathrm{c} \\
0.011 \pm 0.006\end{array}$ & $\begin{array}{c}b \\
0.03 \pm 0.006\end{array}$ & $\begin{array}{c}b \\
0.07 \pm 0.006\end{array}$ & $\begin{array}{c}c \\
0.06 \pm 0.005\end{array}$ & $\begin{array}{c}b \\
0.09 \pm 0.007\end{array}$ \\
\hline $\begin{array}{l}\text { Infected Black } \\
\text { Seed G4 }\end{array}$ & $\begin{array}{c}b c \\
0.04 \pm 0.006\end{array}$ & $\begin{array}{c}b c \\
0.03 \pm 0.006\end{array}$ & $\begin{array}{c}b \\
0.04 \pm 0.006\end{array}$ & $\begin{array}{c}B \\
0.09 \pm 0.005\end{array}$ & $\begin{array}{c}b \\
0.09 \pm 0.005\end{array}$ & $\begin{array}{c}c \\
0.06 \pm 0.007\end{array}$ \\
\hline
\end{tabular}

Values expressed as Mean \pm SE $\quad$ PI $=$ Post Inoculation

Values with different letters in the same column are significantly different

During entire period of experiment, Control group (G2) showed higher bursal indices than (G1) that reflect the higher body weight of G1 due to black seeds growth promoting action. Bursal indices decreased significantly in infected than control (G2) due to diarrhea and alteration in body weight. Thymus indices showed the same result as in bursal indices throughout the observation period. Our result showed that black seed improved the body, bursa and thymus weights and decreased 
Table 4: Effect of black seed on serum protein and its fractionation of experimentally infected chicken with IBDV.

\begin{tabular}{|c|c|c|c|c|c|c|c|c|c|c|c|c|}
\hline \multirow{3}{*}{$\begin{array}{l}\text { Days } \\
\text { PI }\end{array}$} & \multicolumn{2}{|c|}{$\begin{array}{l}\text { Total Protein } \\
\mathrm{g} / \mathrm{dl}\end{array}$} & \multicolumn{2}{|c|}{ Albumin g/dl } & \multicolumn{8}{|c|}{ Globulin $\mathrm{g} / \mathrm{dl}$} \\
\hline & \multirow[b]{2}{*}{$\begin{array}{c}3 \text { days } \\
\text { P.I }\end{array}$} & \multirow[b]{2}{*}{$\begin{array}{l}5 \text { days } \\
\text { P.I }\end{array}$} & \multirow[b]{2}{*}{$\begin{array}{c}3 \text { days } \\
\text { P.I }\end{array}$} & \multirow[b]{2}{*}{$\begin{array}{l}5 \text { days } \\
\text { P.I }\end{array}$} & \multicolumn{2}{|c|}{$\alpha 1$} & \multicolumn{2}{|c|}{$\alpha 2$} & \multicolumn{2}{|c|}{ B } & \multicolumn{2}{|c|}{$\Gamma$} \\
\hline & & & & & $\begin{array}{l}3 \text { days } \\
\text { P.I }\end{array}$ & $\begin{array}{c}5 \text { days } \\
\text { P.I }\end{array}$ & $\begin{array}{l}3 \text { days } \\
\text { P.I }\end{array}$ & $\begin{array}{c}5 \text { days } \\
\text { P.I }\end{array}$ & $\begin{array}{l}3 \text { days } \\
\text { P.I }\end{array}$ & $\begin{array}{c}5 \text { days } \\
\text { P.I }\end{array}$ & $\begin{array}{c}3 \text { days } \\
\text { P.I }\end{array}$ & $\begin{array}{c}5 \text { days } \\
\text { P.I }\end{array}$ \\
\hline $\begin{array}{c}\text { Black } \\
\text { Seed }\end{array}$ & $\begin{array}{c}a \\
3.35 \pm \\
0.08\end{array}$ & $\begin{array}{c}a \\
3.6 \pm \\
0.08\end{array}$ & $\begin{array}{c}c \\
0.90 \pm \\
0.008\end{array}$ & $\begin{array}{c}c \\
1.0 \pm \\
0.01\end{array}$ & $\begin{array}{c}a \\
0.85 \pm \\
0.02\end{array}$ & $\begin{array}{c}a \\
0.85 \pm \\
0.02\end{array}$ & $\begin{array}{c}a \\
0.20 \pm \\
0.01\end{array}$ & $\begin{array}{c}a \\
0.25 \pm \\
0.01\end{array}$ & $\begin{array}{c}a \\
0.30 \pm \\
0.01\end{array}$ & $\begin{array}{c}a b \\
0.40 \pm \\
0.01\end{array}$ & $\begin{array}{c}a \\
1.10 \pm \\
0.07\end{array}$ & $\begin{array}{c}A \\
0.80 \pm \\
0.07\end{array}$ \\
\hline Control & $\begin{array}{c}a b \\
3.1 \pm \\
0.08\end{array}$ & $\begin{array}{c}a \\
3.3 \pm \\
0.04\end{array}$ & $\begin{array}{c}a \\
1.70 \pm \\
0.06\end{array}$ & $\begin{array}{c}a \\
1.8 \pm \\
0.07\end{array}$ & $\begin{array}{c}b \\
0.4 \pm \\
0.04\end{array}$ & $\begin{array}{c}b \\
0.3 \pm \\
0.02\end{array}$ & $\begin{array}{c}a \\
0.3 \pm \\
0.01\end{array}$ & $\begin{array}{c}a \\
0.3 \pm \\
0.01\end{array}$ & $\begin{array}{c}a \\
0.2 \pm \\
0.01\end{array}$ & $\begin{array}{c}a \\
0.6 \pm \\
0.07\end{array}$ & $\begin{array}{c}b \\
0.5 \pm \\
0.06\end{array}$ & $\begin{array}{c}B \\
0.3 \pm \\
0.04\end{array}$ \\
\hline Infected & $\begin{array}{c}b \\
3.0 \pm \\
0.04\end{array}$ & $\begin{array}{c}b \\
3.03 \pm \\
0.06\end{array}$ & $\begin{array}{c}a \\
1.60 \pm \\
0.03\end{array}$ & $\begin{array}{c}a \\
1.7 \pm \\
0.02\end{array}$ & $\begin{array}{c}b c \\
0.31 \pm \\
0.04\end{array}$ & $\begin{array}{c}a \\
0.60 \pm \\
0.07\end{array}$ & $\begin{array}{c}a \\
0.30 \pm \\
0.02\end{array}$ & $\begin{array}{c}a \\
0.30 \pm \\
0.02\end{array}$ & $\begin{array}{c}a \\
0.20 \pm \\
0.02\end{array}$ & $\begin{array}{c}a b \\
0.30 \pm \\
0.02\end{array}$ & $\begin{array}{c}b \\
0.51 \pm \\
0.02\end{array}$ & $\begin{array}{c}C \\
0.10 \\
0.01\end{array}$ \\
\hline $\begin{array}{c}\text { Infected } \\
\text { Black } \\
\text { Seed }\end{array}$ & $\begin{array}{c}b \\
3.0 \pm \\
0.001\end{array}$ & $\begin{array}{c}b \\
3.1 \pm \\
0.05\end{array}$ & $\begin{array}{c}b \\
1.20 \pm \\
0.02\end{array}$ & $\begin{array}{c}b \\
1.3 \pm \\
0.02\end{array}$ & $\begin{array}{c}c \\
0.2 \pm \\
0.01\end{array}$ & $\begin{array}{c}a \\
0.8 \pm \\
0.03\end{array}$ & $\begin{array}{c}a \\
0.3 \pm \\
0.02\end{array}$ & $\begin{array}{c}a \\
0.4 \pm \\
0.02\end{array}$ & $\begin{array}{c}a \\
0.3 \pm \\
0.04\end{array}$ & $\begin{array}{c}b \\
0.2 \pm \\
0.01\end{array}$ & $\begin{array}{c}a \\
0.9 \pm \\
0.06\end{array}$ & $\begin{array}{c}b \\
0.45 \pm \\
0.04\end{array}$ \\
\hline
\end{tabular}


mortality which leads to minimizing the drastic effect of IBD due to IBD due to immunosuppressive response of the virus as it destroys immature B-lymphocytes in the Bursa of Fabricius resulting in immunosuppression (Tanimura et al., 1995).

Table (4) showed that infection with Gumboro virus decreased serum total protein and $\gamma$ globulin level than control at 5 days PI. As decrease in serum total protein level is due to decrease of $\gamma$ globulin level which indicate immunosuppressive response. As virus destroys immature B-lymphocytes, which produce antibodies ( $\gamma$ globulins in the Bursa of Fabricius resulting in immunosuppression) (Tanimura et al., 1995).

Black seeds had no effect on total protein but decreased albumin level while Black seeds treated-infected group (G4) had a significant decrease in both total protein and albumin level as administration of black seed increase both $\alpha 1 \& \gamma$ globulin but after infection, $\alpha 1$ globulin increased without alteration in $\gamma$ globulin comparing to control group. These finding comes in harmony with the result of (Mandour et al., 1995) who found that feeding white Pejin duckling on ration medicated with $5 \%$ black seeds significantly improved immunity as judged by the increased level of gamma globulins but it seemed to have a hepatotoxic effect as proved by a significant reduction in serum albumin. The immunostimulant effect of black seed also proved by (El-Kadi and Kandil 1986) who investigated the effect of black seeds on immune system.

These findings are in harmony with the result of (Hedaya 1995) who found no significant effect on total protein level after injection of rats with $0.8 \mathrm{ml} / \mathrm{kg} \mathrm{b.w}$ of alcohol extract of black seeds. however, the significant decrease of serum albumin in our result not resemble the result of (Nassar, 1997) who found that albumin not significantly changed in chicken fed a ration containing $1 \%$ black seeds for 2 months. 
Table 5: Effect of black seed on serum levels of uric acid and creatinine and enzymatic activity of GOT and GPT of experimentally infected chicken with IBDV.

\begin{tabular}{|c|c|c|c|c|c|c|c|c|}
\hline \multirow{2}{*}{$\begin{array}{l}\text { Days } \\
\text { P.I } \\
\text { Groups }\end{array}$} & \multicolumn{2}{|c|}{ Uric acid mg/dl } & \multicolumn{2}{|c|}{$\begin{array}{c}\text { Creatinine } \\
\mathrm{mg} / \mathrm{dl}\end{array}$} & \multicolumn{2}{|c|}{ GOT U/l } & \multicolumn{2}{|c|}{ GPT U/l } \\
\hline & $\begin{array}{l}3 \text { days } \\
\text { P.I }\end{array}$ & $\begin{array}{l}5 \text { days } \\
\text { P.I }\end{array}$ & $\begin{array}{c}3 \text { days } \\
\text { P.I }\end{array}$ & $\begin{array}{l}5 \text { days } \\
\text { P.I }\end{array}$ & $\begin{array}{c}3 \text { days } \\
\text { P.I }\end{array}$ & $\begin{array}{l}5 \text { days } \\
\text { P.I }\end{array}$ & $\begin{array}{c}3 \text { days } \\
\text { P.I }\end{array}$ & $\begin{array}{c}5 \text { days } \\
\text { P.I }\end{array}$ \\
\hline $\begin{array}{l}\text { Black } \\
\text { Seed }\end{array}$ & $\begin{array}{c}a \\
5.0 \pm \\
1.69\end{array}$ & $\begin{array}{c}b \\
4.43 \pm \\
1.69\end{array}$ & $\begin{array}{c}a \\
0.62 \pm \\
0.05\end{array}$ & $\begin{array}{c}a \\
0.61 \\
\pm 0.05\end{array}$ & $\begin{array}{c}b \\
183 \pm \\
4.3\end{array}$ & $\begin{array}{c}a b \\
181 \pm \\
15.7\end{array}$ & $\begin{array}{c}a b \\
8.9 \pm \\
1.2\end{array}$ & $\begin{array}{c}a b \\
8.7 \pm \\
0.6\end{array}$ \\
\hline Control & $\begin{array}{c}a \\
5.7 \pm \\
0.1\end{array}$ & $\begin{array}{c}b \\
4.6 \pm \\
0.4\end{array}$ & $\begin{array}{c}a \\
0.6 \pm \\
0.005\end{array}$ & $\begin{array}{c}a \\
0.65 \\
\pm 0.05\end{array}$ & $\begin{array}{c}b \\
185 \pm \\
4.4\end{array}$ & $\begin{array}{c}b \\
171 \pm \\
2.8\end{array}$ & $\begin{array}{c}b \\
7.3 \pm \\
1.3\end{array}$ & $\begin{array}{c}b \\
7.0 \pm \\
0.6\end{array}$ \\
\hline Infected & $\begin{array}{c}a \\
5.1 \pm \\
0.2\end{array}$ & $\begin{array}{c}a \\
7.3 \pm \\
0.8\end{array}$ & $\begin{array}{c}a \\
0.63 \pm \\
0.05\end{array}$ & $\begin{array}{c}a \\
0.73 \\
\pm 0.03\end{array}$ & $\begin{array}{c}a \\
213.7 \\
\pm 3.52\end{array}$ & $\begin{array}{c}a \\
214 \pm \\
5.9\end{array}$ & $\begin{array}{c}a \\
13.3 \pm \\
1.2\end{array}$ & $\begin{array}{c}a \\
11.7 \pm \\
0.9\end{array}$ \\
\hline $\begin{array}{l}\text { Infected } \\
\text { Black } \\
\text { Seed }\end{array}$ & $\begin{array}{c}a \\
4.7 \pm \\
0.1\end{array}$ & $\begin{array}{c}b \\
4.2 \pm \\
0.5\end{array}$ & $\begin{array}{c}a \\
0.6 \pm \\
0.05\end{array}$ & $\begin{array}{c}a \\
0.6 \pm \\
0.03\end{array}$ & $\begin{array}{c}a \\
210 \pm \\
4.15\end{array}$ & $\begin{array}{c}a \\
202 \pm \\
5.5\end{array}$ & $\begin{array}{c}a b \\
9.3 \pm \\
0.9\end{array}$ & $\begin{array}{c}a b \\
10.3 \pm \\
0.8\end{array}$ \\
\hline
\end{tabular}

Values expressed as Mean \pm SE $\quad$ PI $=$ Post Inoculation

Values with different letters in the same column are significantly different

Infection with IBDV affect the kidney by increasing the serum uric acid level significantly in the infected group comparing to control at 5 days PI (Table 5). This is confirmed by the pathological finding of Butcher and Miles (2003) who revealed that kidneys appear swollen with prominent tubules and varied in color from gray to dark brown with pale areas. Tubules and ureters sometimes filled with urates indicating nephritis. Administration of black seeds to infected group succeeded to keep ureters without any alteration and restore level of uric acid to normal with no significant difference than control. Our result agreed 
with (Ali and Blunden 2003) who proved that black seeds decrease the elevated uric acid level and not induce any significant adverse effect on liver and kidney functions. It would appear that the beneficial effects of the use of the seeds might be related to cytoprotective and antioxidant actions.

There is no significant change in serum creatinine level among all groups during the whole period of the experiment (Table 5). That mean no elevation of creatinine level in the groups which infected by Gumboro virus. Khafagy et al. (1991) reported dehydration of the subcutaneous tissue and muscles, punctuate hemorrhages and petechiae were common on the muscles of the leg, breast and wings, sometimes hemorrhages and erosions in the proventriculus and gizzard junction. The muscle injury may decrease creatinine (Til et al., 1988) which is proved also by the elevation of GOT activity.

However, no alteration in the level of uric acid and creatinine in infected group treated with black seed because seeds succeeded to ameliorate the adverse effect on the kidneys. Sayed and Nagi (2007) proved that black seeds decreased creatinine level with strong antioxidant properties against Gentamicin induced nephrotoxicity. Khattab and Nagi (2007) said that (TQ) decreased the elevated creatinine and was effective in protecting rats against renal damage possibly via antioxidant activity.

GOT and GPT activity increased significantly 3 rd \& 5th days PI, in infected group than control which indicate liver injury (Table 5), however, GOT elevation also may point to muscle injury. Black seeds administration to infected group failed to correct the change in GOT and still significantly higher than normal control. However GPT activities partially modulated as administration of black seed to group (G4) induce a non significant decrease than infected (G3) and a non significant increase than control (G2). In contrary, Mahmoud and Mansour (2000) said that administration of black seeds oil succeeded particularly to abbreviate the change in both GOT and GPT activities to normal level. 
Table 6: Effect of black seed on blood level of GSH and tissues vitamin $\mathrm{C}$ of experimentally infected chicken with IBDV.

\begin{tabular}{|c|c|c|c|c|c|c|c|c|}
\hline \multirow{3}{*}{ P.I Grouls } & \multirow{2}{*}{\multicolumn{2}{|c|}{ GSH mg/dl }} & \multicolumn{6}{|c|}{ Tissue Vitamin $\mathrm{C} \mathrm{mg} / 100 \mathrm{~g}$ tissue } \\
\hline & & & & & & & & \\
\hline & $\begin{array}{c}3 \text { days } \\
\text { P.I }\end{array}$ & $\begin{array}{c}5 \text { days } \\
\text { P.I }\end{array}$ & $\begin{array}{c}3 \text { days } \\
\text { P.I }\end{array}$ & $\begin{array}{c}5 \text { days } \\
\text { P.I }\end{array}$ & $\begin{array}{c}3 \text { days } \\
\text { P.I }\end{array}$ & $\begin{array}{c}5 \text { days } \\
\text { P.I }\end{array}$ & $\begin{array}{c}3 \text { days } \\
\text { P.I }\end{array}$ & $\begin{array}{c}5 \text { days } \\
\text { P.I }\end{array}$ \\
\hline $\begin{array}{l}\text { Black } \\
\text { Seed }\end{array}$ & $\begin{array}{c}a \\
5.9 \pm \\
0.22\end{array}$ & $\begin{array}{c}c \\
5.03 \pm \\
1.03\end{array}$ & $\begin{array}{c}b \\
50.2 \pm \\
1.9\end{array}$ & $\begin{array}{c}b \\
49.7 \pm \\
1.9\end{array}$ & $\begin{array}{c}a \\
27.5 \pm \\
1.0\end{array}$ & $\begin{array}{c}a \\
28.1 \pm \\
1.1\end{array}$ & $\begin{array}{c}a \\
59.5 \pm \\
2.0\end{array}$ & $\begin{array}{c}a \\
65.2 \pm \\
1.4\end{array}$ \\
\hline Control & $\begin{array}{c}a \\
6.5 \pm \\
0.21\end{array}$ & $\begin{array}{c}b \\
6.7 \pm \\
0.13\end{array}$ & $\begin{array}{c}b \\
53.9 \pm \\
2.0\end{array}$ & $\begin{array}{c}a \\
53.9 \pm \\
2.0\end{array}$ & $\begin{array}{c}a \\
26.8 \pm \\
1.1\end{array}$ & $\begin{array}{c}a \\
26.8 \pm \\
1.1\end{array}$ & $\begin{array}{c}a \\
54.3 \pm \\
2.4\end{array}$ & $\begin{array}{c}a \\
54.3 \pm \\
2.4\end{array}$ \\
\hline Infected & $\begin{array}{c}a \\
5.9 \pm \\
0.15\end{array}$ & $\begin{array}{c}b \\
6.3 \pm \\
0.13\end{array}$ & $\begin{array}{c}a \\
65.7 \pm \\
1.8\end{array}$ & $\begin{array}{c}a \\
54.8 \pm \\
0.5\end{array}$ & $\begin{array}{c}a \\
27.18 \pm \\
2.8\end{array}$ & $\begin{array}{c}a \\
28.2 \pm \\
0.7\end{array}$ & $\begin{array}{c}c \\
28.3 \pm \\
1.02\end{array}$ & $\begin{array}{c}b \\
27.1 \pm \\
1.3\end{array}$ \\
\hline $\begin{array}{l}\text { Infected } \\
\text { Black } \\
\text { Seed }\end{array}$ & $\begin{array}{c}a \\
6.8 \pm \\
0.22\end{array}$ & $\begin{array}{c}a \\
7.8 \pm \\
0.01\end{array}$ & $\begin{array}{c}b \\
52.75 \pm \\
3.9\end{array}$ & $\begin{array}{c}a \\
59.7 \pm \\
1.2\end{array}$ & $\begin{array}{c}a \\
30.6 \pm \\
2.8\end{array}$ & $\begin{array}{c}a \\
25.7 \pm \\
1.7\end{array}$ & $\begin{array}{c}b \\
37.8 \pm \\
1.7\end{array}$ & $\begin{array}{c}b \\
31.4 \pm \\
1.5\end{array}$ \\
\hline
\end{tabular}

In this study, black seeds alone decreased (GSH) content than control (Table 6). However, there was increase in (GSH) content in the infected black seeds group than control. That means that black seeds improve the (GSH) value in the blood after infection. This result parallel to Kaleem et al. (2006) who proved that the oral administration of ethanol extract of black seed significantly improved level of (GSH) in streptozotocin induced diabetic rats For 30 days. Also, El Shenawey et al. (2008) proved that black seeds oil affect on Schisestoma-Mansoni infected mice and elevated the protection by preventing the (GSH) change and most of biochemical parameters. These results confirm the activity of black seeds in stressed conditions like infection.

No significant change in the level of renal ascorbic acid among all groups but hepatic vitamin $\mathrm{C}$ decreased in the infected group than control (Table 6). This agreed with El-Ghannam (1982) who reported that no change in the kidney vitamin $\mathrm{C}$ with a significant decrease in hepatic vitamin $\mathrm{C}$ after Coccidiosis infection. Infected black seeds show 
increase in hepatic Vitamin $\mathrm{C}$ than infected but still decreased than control. It means that black seeds not completely succeeded to alleviate vitamin $\mathrm{C}$ level in hepatic tissues. Bursal Vitamin $\mathrm{C}$ shows a sudden significant increase in infected group 3days PI then returned to normal 5 days PI. Treated of infected group with black seed retain the level to normal.

In Table 7, Infection elevated serum and renal MDA level than control as an indication of increased lipid peroxidation and oxidative stress. Black seeds preserved the MDA level of the serum and kidney of infected birds as normal control.

Table 7: Effect of black seed on serum and tissue levels of MDA of experimentally infected chicken with IBDV.

\begin{tabular}{|c|c|c|c|c|c|c|c|c|}
\hline \multirow{3}{*}{ Groups } & \multirow{2}{*}{\multicolumn{2}{|c|}{ Serum MDA $\mu \mathrm{mol} / \mathrm{L}$}} & \multicolumn{6}{|c|}{ Tissue MDA $\mu \mathrm{mol} / \mathrm{g}$ tissue } \\
\hline & & & \multicolumn{2}{|c|}{ Bursal } & \multicolumn{2}{|c|}{ Renal } & \multicolumn{2}{|c|}{ Hepatic } \\
\hline & $\begin{array}{l}3 \text { days } \\
\text { P.I }\end{array}$ & $\begin{array}{l}5 \text { days } \\
\text { P.I }\end{array}$ & $\begin{array}{l}3 \text { days } \\
\text { P.I }\end{array}$ & $\begin{array}{c}5 \text { days } \\
\text { P.I }\end{array}$ & $\begin{array}{c}3 \text { days } \\
\text { P.I }\end{array}$ & $\begin{array}{c}5 \text { days } \\
\text { P.I }\end{array}$ & $\begin{array}{l}3 \text { days } \\
\text { P.I }\end{array}$ & $\begin{array}{l}5 \text { days } \\
\text { P.I }\end{array}$ \\
\hline Black Seed & $\begin{array}{c}b \\
5.71 \pm \\
0.95\end{array}$ & $\begin{array}{c}b \\
5.35 \pm \\
0.56\end{array}$ & $\begin{array}{c}c \\
4.5 \pm \\
1.2\end{array}$ & $\begin{array}{c}c \\
4.6 \pm \\
0.5\end{array}$ & $\begin{array}{c}a \\
16.0 \pm \\
0.40\end{array}$ & $\begin{array}{c}B \\
16.1 \pm \\
0.56\end{array}$ & $\begin{array}{c}c \\
12 \pm 0.60\end{array}$ & $\begin{array}{c}c \\
11.8 \pm \\
3.0\end{array}$ \\
\hline Control & $\begin{array}{c}b \\
5.82 \pm \\
0.73\end{array}$ & $\begin{array}{c}b \\
5.85 \pm \\
0.75\end{array}$ & $\begin{array}{c}b \\
9.2 \pm \\
1.5\end{array}$ & $\begin{array}{c}b \\
9.3 \pm \\
0.6\end{array}$ & $\begin{array}{c}a \\
16.9 \pm \\
0.48\end{array}$ & $\begin{array}{c}B \\
16.98 \pm \\
0.58\end{array}$ & $\begin{array}{c}b c \\
13.57 \pm \\
0.62\end{array}$ & $\begin{array}{c}b c \\
13.5 \pm \\
0.6\end{array}$ \\
\hline Infected & $\begin{array}{c}a \\
9.77 \pm \\
0.65\end{array}$ & $\begin{array}{c}a \\
9.15 \pm \\
0.60\end{array}$ & $\begin{array}{c}a \\
14.5 \pm \\
1.1\end{array}$ & $\begin{array}{c}a \\
10.7 \pm \\
1.2\end{array}$ & $\begin{array}{c}a \\
19.73 \pm \\
1.9\end{array}$ & $\begin{array}{c}a \\
19.43 \pm \\
0.3\end{array}$ & $\begin{array}{c}a b \\
16.5 \pm \\
1.0\end{array}$ & $\begin{array}{c}a b \\
15.13 \\
\pm 1.2\end{array}$ \\
\hline $\begin{array}{l}\text { Infected } \\
\text { Black Seed }\end{array}$ & $\begin{array}{c}a b \\
7.7 \pm \\
0.71\end{array}$ & $\begin{array}{c}a b \\
7.8 \pm \\
0.20\end{array}$ & $\begin{array}{c}a \\
17.4 \pm \\
0.6\end{array}$ & $\begin{array}{c}a \\
14.96 \pm \\
0.76\end{array}$ & $\begin{array}{c}a \\
21.75 \pm \\
1.36\end{array}$ & $\begin{array}{c}b \\
16.7 \pm \\
1.38\end{array}$ & $\begin{array}{c}a b \\
16.1 \pm \\
0.6\end{array}$ & $\begin{array}{c}a b \\
14.06 \\
\pm 1.3\end{array}$ \\
\hline
\end{tabular}

Bursal MDA level increased than control 3 days PI. Black seeds could not succeed to reduce bursal MDA level as infected black seeds group show significant increase in MDA level than control $3 \& 5$ days PI. This may be due to the destructive effect of the infection on bursa (its target organ)

No significant changes were observed in hepatic MDA level between infected groups and control. However, black seeds alone group 
has a decreased serum and hepatic MDA level significantly than control. This is in harmony with Mahmoud and Mansour (2000) who demonstrated that supplementing the diet with $2 \%$ and $3 \%$ black seeds significantly reduced MDA level in liver. Ilhan et al. (2005) reported that black seeds oil reduced MDA level due to its protective effect against oxidative stress.

Table 8: HI measuring antibody titer against Newcastle \& ELISA measuring antibody titer against IBDV.

\begin{tabular}{|c|c|c|c|c|c|c|c|c|c|}
\hline \multirow[b]{2}{*}{ Groups } & \multicolumn{5}{|c|}{ HI. Titre } & \multicolumn{4}{|c|}{ ELISA titer } \\
\hline & $\begin{array}{c}11 \text { days } \\
\text { old }\end{array}$ & $\begin{array}{c}18 \text { days } \\
\text { old }\end{array}$ & $\begin{array}{l}3 \text { days } \\
\text { P.I }\end{array}$ & $\begin{array}{c}5 \text { days } \\
\text { P.I }\end{array}$ & $\begin{array}{c}14 \text { days } \\
\text { P.I }\end{array}$ & $\begin{array}{l}3 \text { days } \\
\text { B.I }\end{array}$ & $\begin{array}{c}3 \text { days } \\
\text { P.I }\end{array}$ & $\begin{array}{l}5 \text { days } \\
\text { P.I }\end{array}$ & $\begin{array}{c}14 \text { days } \\
\text { P.I }\end{array}$ \\
\hline $\begin{array}{l}\text { Black } \\
\text { Seed }\end{array}$ & $\begin{array}{c}a \\
5 \pm 0.1\end{array}$ & $\begin{array}{c}a \\
3.6 \pm 0.1\end{array}$ & $\begin{array}{c}a \\
4.7 \pm 0.2\end{array}$ & $\begin{array}{c}a \\
3 \pm 0.12\end{array}$ & $\begin{array}{c}\mathrm{a} \\
3 \pm 0.12\end{array}$ & $\begin{array}{c}\mathrm{a} \\
180 \pm 2\end{array}$ & $\begin{array}{c}\mathrm{b} \\
98 \pm 4.4\end{array}$ & $\begin{array}{c}c \\
52 \pm 1\end{array}$ & $\begin{array}{c}\mathrm{c} \\
32 \pm .4\end{array}$ \\
\hline Control & $\begin{array}{c}b \\
3 \pm 0.6\end{array}$ & $\begin{array}{c}b \\
3 \pm 0.12\end{array}$ & $\begin{array}{c}c \\
2 \pm 0.13\end{array}$ & $\begin{array}{c}b \\
1.7 \pm 0.1\end{array}$ & $\begin{array}{c}\mathrm{b} \\
1.7 \pm 0.1\end{array}$ & $\begin{array}{c}c \\
68 \pm 3.5\end{array}$ & $\begin{array}{c}c \\
41.9 \pm \\
1.3\end{array}$ & $\begin{array}{c}c \\
29 \pm \\
0.26\end{array}$ & $\begin{array}{c}\mathrm{c} \\
10 \pm 0.0\end{array}$ \\
\hline Infected & --- & --- & $\begin{array}{c}d \\
1.3 \pm \\
0.06\end{array}$ & $\begin{array}{c}c \\
0.7 \pm \\
0.07\end{array}$ & $\begin{array}{c}\mathrm{d} \\
0.31 \\
\pm 0.06\end{array}$ & $\begin{array}{c}b \\
110 \pm 4.5\end{array}$ & $\begin{array}{c}\mathrm{a} \\
1648.9 \\
\pm 128.3\end{array}$ & $\begin{array}{c}a \\
16234 \pm \\
111.3\end{array}$ & $\begin{array}{c}a \\
7470 \\
\pm 469\end{array}$ \\
\hline $\begin{array}{c}\text { Infected } \\
\text { Black } \\
\text { Seed }\end{array}$ & --- & --- & $\begin{array}{l}b \\
3 \pm \\
0.13\end{array}$ & $\begin{array}{c}b \\
1.7 \pm \\
0.07\end{array}$ & $\begin{array}{ll} & \mathrm{c} \\
1 \pm 0.1\end{array}$ & $\begin{array}{c}\mathrm{a} \\
196 \pm \\
5.3\end{array}$ & $\begin{array}{c}b \\
109.9 \pm \\
0.6\end{array}$ & $\begin{array}{c}\mathrm{b} \\
4746 \pm \\
523.4\end{array}$ & $\begin{array}{c}\mathrm{b} \\
517 \\
\pm 4.3\end{array}$ \\
\hline
\end{tabular}

Results of immune assay (Table 8) was conducted to determine the efficacy of black seeds as non specific Immunostimulant for an active vaccine of ND and IBD in vivo $(\mathrm{G} 1, \mathrm{G} 2)$, and examine antibody titre after Gumboro experimental infection $(\mathrm{G} 3, \mathrm{G} 4)$ in comparison with $(\mathrm{G} 1, \mathrm{G} 2)$. HI titer against ND and ELISA titer against IBD were clearly showing significant increase in black seeds over control during the entire period of observation. These results were agreed with Nassar (1997) who reported that total protein and globulin were significant increased in chickens received a ration containing 1, 2\% black seeds. These results are due to the superiority of using immunostimulant plants as immunopotentiator. 
After experimental infection with IBDV there is significant decrease in HI titre in infected group G3 comparing to G4 due to its immunosuppressive effect on the vaccinal and humoral immunity, our results were Explained with Butcher and Miles (2003).

Using black seeds overcome and compensates this immune deficiency that attributed to the drastic effect of Gumboro virus infection.

ELISA antibody titer against IBDV applied for detection of persistent antibody titer to determine the lowest antibody level which was the proper time for experimental infection with the virus (using IDEXX-USA) (Half life of antibodies in fast growing broiler about 3 days with protective titer about 200) according to De Wit (2001), that corresponding to the 24th day of age. Our results were agreed with Allan et al. (1972).

After infection with Gumboro virus ELISA titer in infected group (G3) was significantly increased till end of observation period over the other groups. That significant increase in ELISA titre rebacked to the decrease in body immunity. Infected black seeds (G4) showed increased titer than non infected groups, due to immunopotentiator effect of Black seeds as mentioned before.

Gross and Post mortem lesion: experimentally infected birds showed whitish or watery diarrhea and soiling of vent feathers. This is followed by depression, ruffled feathers, affected birds become dehydrated and in terminal stages of the disease, had a subnormal temperature. After 72 hour scarified birds showed sever congestion in their carcasses especially in non treated groups. After $96 \mathrm{~h}$, there were petecheal hemorrhages in the leg and thigh muscle as IBDV interferes with the normal blood clotting mechanism, hypertrophy of proventriculus gland, hypertrophy of spleen and bursa with edema and creamy exudates in bursa, petecheal hemorrhage on ceacal tonsils with sever congestion in the kidney. $6^{\text {th }}$ day after infection, the bursa of Farici diminished in size and atrophies. Necrosis and depletion also occur in the secondary organs, including the spleen, thymus glands, and ceacal tonsils. These organs are typically affected less severally than the BF and may recover following infection. Generally, there was significant decrease in gross lesion and post mortem lesion in Black seeds treated and infectecd group (G4) in comparison with infected group (G3) during the entire period of experiment our results were agreed with Butcher and Miles (2003). 
Figure (a): Chick from infected group showed severe depression, ruffled feathers, diarrhea and unable to stand.

Figure (b): Thigh muscle from infected group showed petecheal hemorrhage

Figure (c): Bursa Fabricious (the left) from infected group showed hypertrophy and signs of inflammation compared with control.

Figure (d): Proventericulus glands showed enlargement.

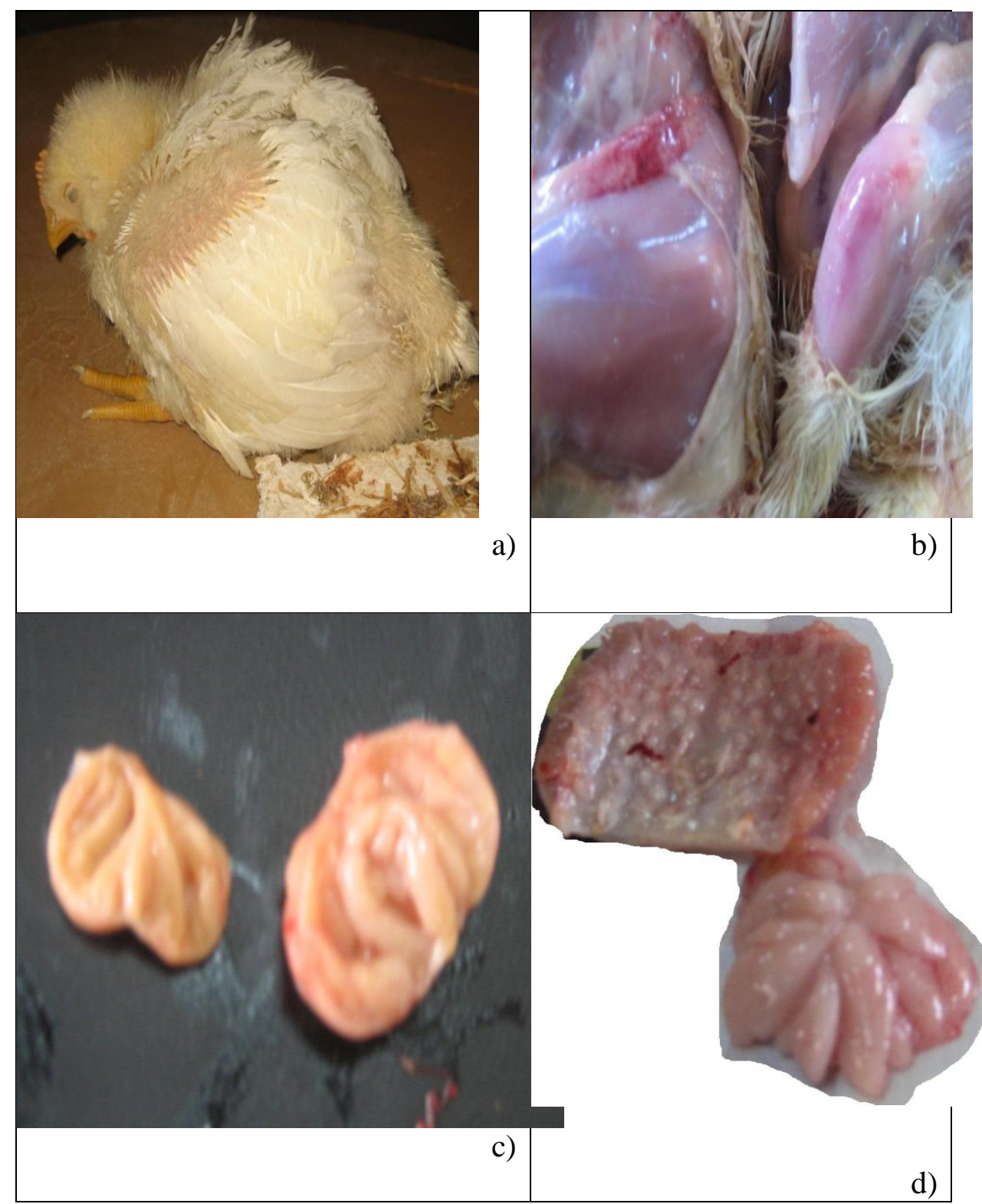




\section{REFERENCES}

Abdel-Rahman Omar; Aini Idris; Mohd Hair Bejo; Hairul Aini Hamsah and Kong Lih Ling (2007): Differetiating strains of Gumboro disease.Dr Nayan Kanwal, FRSA, ABIM Home Page Technology News 19-36 GMT.

Abdo, Z.M.A. (2004): Effect of phytase supplementation on the utilization of Nigella sativa seeds meal in broiler diets. Egyptian poultry science journal. (Vol. 24) (No. 1) 143-162.

Ahmed, AS. (1991): Disease problems in Egypt. Aerosols News letter of the W.V.A., 4: 13-14.

Ali, BH. and Blunden, G. (2003): Pharmacological and toxicological properties of Nigella sativa. Phyto. Res. Apr: 17(4): 299-305.

Allan, W.H.; Faragher, J.T. and Cullen, G.A. (1972): Immunosuppression by the infectious bursal agent in chickens immunized against Newcastle disease. Vet. Rec. 90: 511-512.

Ayoub, NK. and Malek, G. (1976): Identification of the pathogen of Gumboro disease in Egypt. J. Vet. Med. 31: 106-108.

Bartels, H. (1971): Human Gesellschatt. Biochemich. And Diagnostic mbh. Max -Planck. Ring 21 D-65205 Wiesbaden. Germany. Method of Clin. Chim. Acta. 32, 81.

Beutler, E.; Duran, O. and Kelly, B. (1963): Improved method for the determination of blood glutathione. J. of lab and clinic. Med. 61.882 .

Butcher, G.D. and Miles, D.M. (2003): Infectious Bursal Disease (Gumboro) in commercial broilers. Veterinary Medicine-Large Animal Clinical Sciences Department, Florida University.

Cosgrove, AS. (1962): An apparently new disease of chicken Avian nephrosis. Avian Dis. 6: 385-389.

Dalia Mansour (2003): Studies on cryptosporidium infection in chicken. PH D thesis Poultry and Rabbits Med. Dep. Facul. Vet. Med. Suez canal U. 
De Wit, JJ. (2001): Gumboro disease: estimation of optimal time of vaccination by the Deventer formula. Annual report and proceedings of COST Action 839: Immune suppressive Viral diseases in Poultry (pp, 170:178) Luxembourg.

Duncan, DB. (1955): Multiple range test and F-test. Biometrics, 11:1-42.

El-Batrawy, AM. (1990): Studies on sever outbreaks of infections bursal disease. I-the natural and experimental disease. Proceeding. 2nd Scientific conference of the Egyption Veterinary Poultry Association, 12-14 March ,Cairo: 239-252.

El-Ghannam, (1982): Vitamin C content of blood and tissues in chicken infected with caecal coccidiosis and New castle disease. M.V.Sc Thesis, Faculty of Veterinary Medicine.

El-Kadi, A. and Kandil, O. (1986): Effect of Nigella Sativa on immunity. Proceeding of the $4^{\text {th }}$ international conference on Islamic medicine, Kuwait. Bull Islamic 4: 344-8

El-Sergany, HA.; Ann; Moursi; Saber, MS. and Mohamed, MA. (1974): preliminary investigation on the occurrence of Gumboro in Egypt. Egypt. J. Vet. Scin., 11: 7.

El-Shenawy, NS.; Soliman, MF. and Reyad, SI. (2008): The effect of antioxidant properties of aqueous garlic extract and Nigella sativa as anti-schistosomiasis agents in mice. Rev. Inst. Med. Trop. Sao. Paulo. 50(1): 29-36.

Giambrone, JJ. and Ronald, PE. (1986): Vaccination of one day old broiler chicks against Newcastle and infectious bursal disease using commercial live and/or inactivated vaccines. Avian Dis, 30(3): 557-562.

Gornal, AC.; Bardawill, CJ. and David, MM. (1949): Colorimetric determination of total protein. J. Biol. Chem. 177: 751

Hanan, El Dahshan (2002): Comparative clinic-pathological studies on some immunostimulants with relation to some poultry diseases. Dep. of Clinical Path. Facul. Vet. Med., Suez Canal University.

Hanson, RP.; Helmboldt, CF.; Reid, MW. and Yoder, HF. (1978): Newcastle disease in hofstad Diseases of poultry $7^{\text {th }}$ Edition lowa state. Calnek M S. University Press, Ames 513-535. 
Harrison, GJ. and Harrison, LR. (1986): Clinical Avian Medicine and Surgery. $3^{\text {rd }}$ ed W.B saunders Company. Philadelphia, London. Toronto.

Hedaya, SA. (1995): Effect of Nigella Sativa seeds extract on some hematological and biochemical parameters in rats. Alex. J. Vet. Sci., 11(2): 95-99.

Helmboldet, CF. and Garner, E. (1964): Experimentally induced Gumboro disease (IBD). Avian Dis. 8: 561-575.

Ilhan, A.; Gurel, A.; Armutcu, F.; Kamisli, S. and Iraz, M. (2005): Antiepileptogenic and antioxidant effects of Nigella Sativa oil against pentylenetetrazol-induced Kindling in mice. Neuropharmacology, 49: 456-464.

Kaleem, M.; Kirmani, D.; Asif, M.; Ahmed, Q. and Bano, B. (2006): Biochemical effects of Nigella sativa $L$ seeds in diabetic rats. Indian J. Exp. Biol. 44(9): 745-8.

Keneton Kreager, D.V.M. (2003): Optimal time for Gumboro Vaccination. Technical Bulletion. Aplication of Hy-line international 1755 west Lakes Park Way. Avian Disease, Vol. 30 No1.

Khafagy, AK.; Assia, M.; El-Sawy; Kouwenhoven, B.; Vielitz, E.; Ismail, IM.; Amer, AA.; Sultan, HA. and El-Gohary, AE. (1991): Very virulent IBD. Vet. Med. J. Giza. 39: 299-317.

Khattab, MM. and Nagi, MN. (2007): Thimoquinone supplementation attenuates hypertension and renal damage in nitric oxide deficient hypertensive rats. Phytother Res. 21(5): 410-4.

Lukert, PD. (1992): IBD Veterinary Diagnostic Virology, A practitioner Guide, edited by Castro, and Heupoirdio, W.F., Moshv, Year Book, Ino.

Madbouly, HM.; El-Sanousi, A.; Saber, MS.; El-bagouri, G.; Abd ElBarr, NA.; El-tarabili, M. and Reda, IM. (1992): Infectious bursal disease virus infection among Egyption poultry flocks : I. Detection and isolation of the virus. Vet. Med. J. Giza, 40(2): 55-62.

Mahmoud, NN. and Mansour, AM. (2000): Protective effect of thymoquinone against doxorubicin-induced cardiotoxicity in 
rats. A possible mechanism of protection. Pharmacological Res. 41: 283-289.

Mandour, A.; Mahmoud, K.; Azza, AW.; El-Agamy, EI. and Omyma, R. (1995): Effect of aflatoxin and Nigella sativa seeds on serum proteins and its electrophoretic pattern in white pekin ducklinga. First Eguption hungarian poultry coferance, 17-19 sept.,Alexandria Egypt 429-439.

Mansour, MA.; Nagi, MN.; El-Khatib, AS. and Al-Bekairi, M. (2002): Effect of thymoquinon on antioxidant enzyme activities lipid peroxidase in different tissues of mice: a possible mechanism of action . Cell biochem.Funct.20(2): 143-51.

McFerran, JB. (1993): Infectious Bursal Disease. Virus infections of birds 213-228.

Nabila, M.; El Bagir; Aziza; Hama; Rania, M.; Hamed,; Ahmed, G.; Abd El Rahim and Anton, C.B. (2006): Lipid composition of egg yolk and serum in laying hens fed diets containig Bleck cumin (Nigella sativa). International journal of poultry science 5 (6): 574-578.

Nassar, M.H. (1997): Pharmacological and toxicological studies on Nigella sativa. Ph. D. Thesis. Fac. Vet. Med., Alex.Univ. oral toxicity of potassium nitrite in A 13-week drinking- water study in rats. Food and Chemical Toxicology 26 (10), 851-859.

Paul, BK.; Das, SK.; Badhy, SC.; Amin, MR.; Amin, KMR. and Banik, SC. (2004): Effect of Exiting and Imposed Vaccinationnon Body Weighet Againest Gumboro in Broiler Under Farm Condition. International Jornal of poultry Scinece 3 (10): 655-657.

Ritzmann, S.E. and Daniel, J.C. (1982): Serum Protein Abnormalities: Diagnostic and Clinical Aspects. Little, Alan R. Liss Inc., 1982.

Roe, JH.; Mills, MB.; Osterling, MJ. and Domron, CM. (1948): Determination of vitamin C. by dinitrophenylehydrasin method. J.Bio.Chem: 174-201.

Sayed-Ahmed, MM. and Nagi, MN. (2007): Thymoquinone supplementation prevents the development of gentamicin- 
induced acute renal toxicity in rats. Clin. Exp Pharmacol. Physiol. 34(5-6): 399-405.

Scherwin, JE.; Kaplan, LA.; Pesce, A.J. and Kazmierczak, SC. (2003): Liver functional. Clinical Chemistry: Theory analysis correlation.

Tanimura, NK.; Tsukamoto, K.; Nakamura, M.; Narita and Maeda, M. (1995): Association between pathogenicity of IBD virus and viral antigen distribution detected by immunohistochemistry Avian dis. 39: 9-20.

Til, H.P.; Falke, H.E.; Kuper, C.F. and Williams, M.I. (1988): Evaluation of the oral toxicity of potassium nitrite in A 13 week drinking- water study in rats. Food and Chemical Toxicology 26 (10), 851 -859.

Tsukamoto, K.N.; Tanimura, H.; Hihara, H.; Shirai, J.; Lmai, K.; Nakamura, K. and Maeda, M. (1992): Isolation of virulent infections bursal disease virus from field outbreaks with high mortality in Japan. J. Vet. Med. Sci. 54: 153-155.

Yoshioko, TN.; Kawada, T.; Shimoda, M. and Mori, T. (1979): Lipid peroxidation in maternal and cord blood and protective mechanisms against activated oxygen toxicity in the blood. Am. J. Obestetric. Gynecology. 135: 372-376.

Young, DS. (2001): Effects of disease on clinical lab. Tests, $4^{\text {th }}$ ed AACC. Spainreact diagnostic Compony. Spain

Zaoui, A.; Cherrah, Y.; Alaoui, K.; Mahassine, N.; Amarouch, H. and Hassar, M. (2002): Effects of Nigella sativa fixed oil on blood homeostasis in rat. Journal of Ethnopharmacology volume 79, issue 1: 23-26. 
Assiut Vet. Med. J. Vol. 57 No. 131 October 2011 